\title{
REFLECTION OF K.H. AHMAD DAHLAN'S EDUCATIONAL IDEAS FOR SCHOOL DEVELOPMENT
}

\author{
Suripto \\ STAI Muhammadiyah Tulungagung \\ ripta_jatim@yahoo.com
}

\begin{abstract}
This research was aimed to reflect the form of K.H. Ahamad Dahlan's educational ideas in schools. The kind of this reasearch was qualitative with multi sites approach. Reasearch was conducted at MTs Muhammadiyah 2 and Muhammadiyah 1 Vocational School - Trenggalek.The object of this research was the form of K.H. Ahmad Dahlan's educational ideas whereas the subject was all the schools administrators. Data were collected through deep interview, documentation and observation techniques. Data validity was tested with; credibility, transferability, and confirmability. Data analysis model was interractionally each other; data reduction, data presentation, conclusion withdrawal, and verification. The research result were; first, at MTs Muhammadiyah 2, the form of K.H. Ahmad dahlan's educational ideas covered: Muhammadiyah values, such as (a). TBC eradication, worry attitude towards the improvement of fundamentalist religious culture in the society (LDII), (b). Willingness to sacrifice attitude grown by the school founders' core team, organizers, and administarators; (c). The spirit of dakwah and dedication for the nation and the religion. Second, at Muhammadiyah 1 Vocational School, it covered (a). Charity effort movement for all (rahmatan lilalamin); (b). Amar maruf nahy munkar was formed in the construction of all field of life, (c). Working was the spirit of movement organization.
\end{abstract}

Keywords: educational ideas, school development 


\section{INTRODUCTION}

There were many values of K.H. Ahmad dahlan's ideas related to oneness, Islam, Indonesia, humanity, eduacation, and even culture. His view about the nature of human creation which was attributed to education was that human had double roles. They were as a servant and as Allah's representative on earth. As khalifah on earth (QS.51:56, QS.03:102), human had to give benefit for all creations. The role of khalifah indeed was a part of dedication process (servant role), as the manifestation of his hu-manity quality. Meanwhile, the role as servant had a more value if they could give benefit at most for the surrounding society. Here was one of the fundamental considerations of education implementation which was concepted by K.H. Ahmad Dahlan (Sucipto, 2010, p. 119). It was for that reason, education accomplishment was aimed to form human who obeyed their God, which was reflected in their thinking pattern, attitude pattern, and behavior pattern. They were also able to internalize god's traits as the murobby for all the universe and its contect. However, in his view, K. H Ahmad Dahlan saw that many leaders had not given attention to the goodness and welfare of human beings. They only cared their own group and community, and even their own bodies (Hefner, Mulyadi, \& Mulkhan, 2008, p. 40).

Meanwhile, the goal of Muhammadiyah education as uttered by $\mathrm{K}$. H. Ahmad Dahlan was to create kyai which was intellect, or ulama which was intellect, and intellect which was ulama; as he often told his students, "Be advanced kyai, and for Muhammadiyah" (Sucipto, 2010). Idea of such education institution needed the support from good institution culture. Development of qualified school culture could be started by reflecting values and spirits pioneered by a modernist educational figure such as K.H. Ahmad Dahlan. The development of education institution which was dug from the settled and charactered culture values had to be done through a continuous set of process and habituation to make a certain pattern (Malik, Sudrajat, \& Hanum, 2016, p. 105). The development of school culture could be focused to the three basic aspects. They were (1) teaching-learning process, (2) school leadership and management, (3) school culture (Zamroni,
2001, p. 148). School culture was closely related to the vision had by the principal (Zamroni, 2001). Principal who had vision to face the school challenges in the future would be more successful in building the school culture. It was similar to what K.H. Ahmad Dahlan had done in early stages of Muhammadiyah foundation, who built coope-ration with all sides.

The concept of school culture as understood above had given a basic reference in its implementation at some Muhammadiyah schools including MTs Muhammadiyah 2 and Muhammdiyah 1 Vocational School - Trenggalek.The principals developed their visions and missions through formation of values, norms, and habituation as a process of school culture achievement by involving all the internal and external institution components, which were based on The Quran and Hadits, within which its implementation was elaborated from K. H Ahmad Dahlan's educational ideas. This culture basic principal was a system of ideas or notion which was used together as a reference in institution management and also as the students' parents' credential given to schools. School culture understood by the research subject was as an involvement process of all school internal elements, school committe, and the society.

Some researchs related to the focus of this research may be mapped into three big groups as follows. They were: (1) principal leadership and qualified school, conducted by Abdullah (2007), Samidjo (2008), Imron, (2009), and Munastiwi (2010), (2) Qualified school and school culture, conducted by Suharman (2010), Moerdyanto (2012), and Sudharto; (3) Muhammadiyah school and qualified school, conducted by Nurhadi \& Sudar, comparing philosophy and educational concept pioneered by Ki Hajar Dewantoro, K. H. Ahmad Dahlan, and K. H. Hasyim Asyari; Darmawan (2008), went over about method in Islamic education learning; Al-Faruq, went over about comparison between K. H ahmad Dahlan's humanist education and Paulo Freire's; and the last, Dyah Kumalasari's research about religion character-based education.

This research was the continuity and/or the deeper discussion of the previous researchs. Information about the values and spirits reflected from K. H. Ahmad Dahlan's 
educational ideas then would become basis for quality development in Muhammadiyah schools. It was to complete information about the importance of Muhammadiyah educational philosophy cornerstone which widely and really give contribution to the nation and its people. It was hoped that this reasearch gave science and comprehensive contribution by exploring things had done and based on the reflection of K. H. Ahmad Dahlan's educational ideas. Based on the analysis, this discussion was aimed to analyse the form of $\mathrm{K}$. H. Ahmad dahlan's educational ideas at MTs Muhammadiyah 2 and Muhammadiyah 1 Vocational School - Trenggalek.

\section{RESEARCH METHOD}

Type of this research was qualitative with multi sites approach. Research was conducted at MTs Muhammadiyah 2 and Muhammadiyah 1 Vocational School - Trenggalek, East Java. The research object was all things became the focus of the research itself, whereas the subjects were the principals, viceprincipals, founders/organizers, and teachers. Data was collected through a deep interview, documentation, and observation techniques. To measure the data validity, it used; credibilty, transferability, dependability, and confirmability. Data was analysed gradually and interactionally, data reduction, data presentation, conclusion withdrawal and verification.

\section{Reflection of KH. Ahmad Dahlan's Educational Ideas at Both Sites}

\section{MTs Muhammadiyah Gandusari}

Research was focused at MTs Muhammadiyah 2 Trenggalek. This institution was formerly the continuity of Muhammadiyah Junior High School, Gandusari. The establishment of Muhammadiyah junior high school Gandusari was almost at the same time as MI Muhammadiyah Gandusari which was pioneered by $\mathrm{H}$. Burhanuddin. At that time he was just finished his education at Gontor Modern "Pesantren" in 1967. In the time Muhammadiyah Junior high School Gandusari was established, the people had not known Muhammadiyah. Burhanuddin invited a speaker, Kasman Singodimejo, a centre $\mathrm{Mu}-$ hammadiyah organizer (PPM), to a big Quran recitation in Gandusari. At that time, Kasman was a Muhammadiyah figure which was known as a great orator who was able to hypnotize his listeners to stay where they were until an event was over. Kasman's arrival in Gandusari was made a benefit by Burhanuddin and friends to mobilise the society to build a Madrasah Ibtidaiyah (MI) education institution and a junior high school. Society was so enthusiastic that they voluntarily and actively involved directly in establishing the two institutions. After they were established, Burhanuddin added the name of "Muhammadiyah" at the back of the MI and the Junior High School.

The altering name with "Muhammadiyah" word caused conversation and disappointment among the local society. However, as the time passed, Burhanuddin and friends could cope with that condition well. That way, according to the founders, was part of institution establishment strategy and as an effort of Muhammadiyah development in Gandusari subdistrict. In its development, those education institutions gave benefit to the society of Gandusari and its surrounding. Development of MI and Junior High School then gained more place in people's hearts. . It was caused by good management applied by the organizers and administators. Good administration was effective in growing and developing the institutions by gaining people's trust to send their children to study at the two Muhammadiyah institutions.

Socio - religio condition of people in Gandusari at the mean time was mostly followers of Nahdatul Ulama (Nahdlyin), and smaller part of it was followers of LDII religious organization. LDII's teaching was considered very strict so that it gained less interest from people to follow. This chance was caught by Burhanuddin and friends to develop Muhammadiyah concept in Gandusari, which was mainly helped by H. Manab and friends, who were from Wonanti village.

Then, the society had a great enthusiasm to send their children to study at MI and Muhammadiyah Junior High School which made those institutions came to the peak of advancement. This indeed influenced the development of dakwah and charity effort of Muhammadiyah in Gandusari. It happened that branch leaders of Muhammadiyah in Gandusari and Watulimo were very respected 
since their charity efforts in education field were more successful than any other Muhammadiyah branches. The charity efforts in those two branches played a great role towards the achievement of Muhammadiyah leadership (PDM) in Trenggalek Regency.

For the next the dynamic socio-religio condition in Gandusari society and management pattern of Muhammadiyah branch leadership underwent a degradation process which made setbacks towards the charity efforts of Muhammadiyah Junior High School. The establishment of two State Junior High schools was also one of dominant factors in decreasing people's interest to send their children to Muhammadiyah Junior High School. State status became the trigger of people's greatest interest to send their children to study at the new schools. H. Burhanuddin, the founder of Muhammadiyah Junior High School, was even influenced and he sent his children to Gandusari State Junior High School. His attitude became a significant factor in decreasing people's trust to send their children to study at Muhammadiyah Junior School. The worst happened in the 90's, when Muhammadiyah Junior High School only received 5 new students. Two main factors, that was the decreasing of people's interest and the existence of two state junior high schools, made the Muhammadiyah organizers thought to establish a new institution which was named MTS Muhammdiyah.

Another factor, which became the background of the establishment of MTS Muhammdiyah Gandusari, was the signal from the Department of Religion showing that there was an ease in handling the establishment permit of new schools. This condition then was used by branch leader of Muhammadiyah Gandusari to make the establishment of MTS Muhammadiyah came true. However, it was not an easy process for organizers and administrators to establish MTS Muhammadiyah all at once. Started from Muhammadiyah branch leader and administrators, including the teachers, were united to fight to raise MTS Muhammadiyah. All teachers were teaching without being paid and sincerely using their own money to buy chalks for the need of teaching. There was also an organizer who voluntarily lent his car to be used by the schools to go outside Gandusari, for example to join competitions or go to other schools and even to handle things to East Java $\mathrm{Mu}-$ hammadiyah leader.

The spirit of of all organizers and administrators was worthy appreciated by all sides, including from Trenggalek Muhammadiyah leader. Their struggle to establish and develop the institution was good enough. They didn't feel tired, from the meeting of establishment preparation until it was established. The meetings were presented by all Muhammadiyah branch leaders, school organizers and administrators as said by the respondent, "The need of establishing MTS Muhammadiyah is fixed, and becomes the desire of all Muhammadiyah branch leaders, so that a core team is formed to implement the program." The core team worked from inviting all branches and area figures, planning and making important meetings, handling permission to Department of Religion in Trenggalek Regency and East Java Poivince, including to East Java Muhammadiyah organizers. (W.SW-01.REP01.03042016).

The spirit of all stakeholders to establish the institution, for the researcher was interesting to discuss deeper, what values became the triggers of so. Their desire was that Muhammadiyah charity effort could not be subsided. If there was somehing subsided, there had to be the substitution. That became the general view at Gandusari Muhammadiyah branch leader. This desire was based on K.H. Ahmad Dahlan's idea that establishing charity effort of educational institution was part of amar ma'ruf nahu mungkar. Fighting idiocy, poverty, and the low level of society's health was rooted from the low level of society's education. Increasing the society's education quality and quantity was part of gaining and filling the nation's independence. It was only with high education, society's participation in nation construction will increase as well.

The next step was all organizers determination to establish MTS Muhammadiyah. One of the considerations was that MTS didn't have a state status. This thing was uttered by respondent to the researcher. "After all organizers agreed, MTS Muhammadiyah was going to be built in the same location as Muhammdiyah Junior High School. It was located at waqaf land on the west side of Muhammdiyah Junior High School." Next, they formed a core team who would handle 
the permission matter and the construction. Consideration of establishing MTS was that there was no state or private MTS in Gandusari so it was possible to gain positive response from the society. Meanwhile, Muhammadiyah Junior High School still continued to operate until their last 5 students graduated. (W.SW-02.REP01.04042016)

According to the respondent's confession who was also an important witness and founder in establishing MTS Muhammadiyah, spirit in the institution establishment was aimed not to make Muhammadiyah charity effort subsided, but to make it more. As he said to the researcher, "Muhammdiyah and charity effort are two things cannot be separated. If there is organizer, there will be charity effort." Muhammadiyah had to work, do charity effort, as its founder, K.H. Ahmad Dahlan, who always did charity effort, whose house was used as the first school established by Muhammadiyah. This was part of Surah $A l$ Maun implementation. Form of Muhammadiyah charity effort may include any kinds of activities as long as they were suitable to the organizer programs and not against the Islamic syariah. (W.SW-02.REP01.04042016)

K.H. Ahmad Dahlan's spirit in developing dakwah with any kind of forms inspired one of the organizers to present $\mathrm{Mu}-$ hammadiyah dakwah which was suitable to the needs of Gandusari society and its surrounding. According to the organizer's confession, at the time being, religious school was still possible and the society still needed it. The unavailability of madrasah and junior high school which was suitable to the needs of the society, as he said to the researcher, "Educational charity efforts of Muhammadiyah Gandusari should be improved if possible, especially the field of education which is different from the existed schools." This was used to accomodate children from Gandusari and its surrounding who were not accepted in state schools.. This thing was supported by willingness to help the government in finishing the illiterate eradication program. There should be more children who could enjoy schools. Thus, the organizers' spirit, besides based on K.H. Ahmad Dahlan's teaching and Islamic values, it was also caused by the willingness to help the government to make 9 years studying compulsory program come true. (W.SW-03.REP01.04042016)
Establishing MTS Muhammadiyah for a greater part organizers was meant to straighten the Islamic syiar, in the time where groups which were considered to mislead the Islamic teaching started to come up. One of which was LDII. LDII's concept was considered to mislead the Islamic teaching. It taught a strict attitude towards people outside the group. This thing was delivered to the researcher, "Religious groups exist at that time were NU, Muhammadiyah, and LDII. Muhammadiyah and LDII had less followers, Gandusari was still managed by NU. LDII's concept was very strict towards outside people or groups. For example, when an outsider did his worship at LDII's mosque, it had to be cleaned since outsiders were considered dirty and kafir. This strict concept gave birth to the ideas of Muhammdiyah figures to make dakwah institutions which had a more moderate view by establishing new education institutions which was different from the existed institutions. It was hoped that society's interest would increase to send their children to religious-based schools. (W.SW03.REP01.04042016)

Gandusari was a suburb area of Trenggalek city. It was surrounded by mountains. The geographical condition influenced the culture and the way of thinking of the society. In religious practices, most of them still mixed the Islamic teaching with things outside such as superstitions, bidah, and churafat. These practices motivated the organizers and the core team to bring up their dakwah through education institutions ASAP. Practices of superstitions, bidah, and churafat at that time were still done by Gandusari society. There were also groups in society who mixed the worship with activities outside the Islamic teaching such as kenduren under the shady trees. Kenduren at that time was still connected to the crops and agriculture. There was belief saying that some places and some religious figures had a supernatural power. (W.SW-02.REP01.04042016)

Activities and worship which were mislead from the Islamic syariah made the organizers and figures of Muhammadiyah branch in Gandusari worried. It became the main discussion in their regular meetings. They especially discussed about how to return the purity of their belief and worship. Besides using oral dakwah in routine recitations in 
mosques and other general recitations, founders concluded that real actions in developing dakwah was far more important. It may be in the form of establishing religion based education institution which was hoped to be the field of real dakwah in the society, especially for children in school age as the heirs of Gandusari society in the future.

Dakwah in a wider understanding had been practiced by Gandusari Muhammadiyah branch leader by establishing a religous-based school. To socialize the Islamic Syariah in each learning, it was compulsory for each student to join religious activities as stated in the students ethic codes. In clause number 7 it was stated that: first, each student was compulsory to do the worship based on the syariah. Second, each student had to join any religious activities held by madrasah such as: Dhuha worship, Dhuhur worship in jamaah, and tahtimul Quran visitation. Dhuha worship was aimed to accustom the students to be diligent in doing sunnah worship so that in the future they would not be lazy in doing it. It was the same for jamaah worship habituation, since a good religious education was the ones directly practiced in the students' daily life.

Another meaning from the effort of establishing education institution was to inherit the values developed by K.H. Ahmad Dahlan. That was for preparing experts who were able to inflame spirit to seize the nation's independence. Thus, in the independence era, the values developed were the ways to fill and participate in the process of nation's country establishment. In the independence era, nation's contribution was still needed especially for filling the independence in all aspects, including in education. For example, Muhammadiyah contributed in giving birth education institutions which produced human resource which was able to be leader and give benefit fot its society community. According to respondent, those were values developed in discussions conducted to unite visions in establishing MTS Muhammadiyah. He said, "For Muhammadiyah, important contribution for filling the independence was by establishing the education institution." After independence, there was lack of human resource. So it was for that reason, each nation's component needed to unite their steps in accordance with their own capacity and field to contribute in preparing a better gene- ration. In education field, effort could be done was by establishing a good education institution which was suit to the needs of each society. (W.SW-03.Rep02.04042016)

Establishing education institution, for Gandusari Muhammadiyah branch leader was not only for business goal. This was strengthened by real action that all were ready to sacrifice time, energy, wealth, and even other things needed for the institution. In the early stage of the institution establishment, organizers had sacrified a lot. Even for the institution's daily needs, they took their own savings, teachers and principal were unpaid, and they often chipped in to fulfill the needs. According to their confession, those things were form of sacrifice for the nation and country's importance.

K.H. Ahmad Dahlan had taught a value that Muhammadiyah struggle area was Islam and The United Country - Republic of Indonesia. Between Islam and nation was one unity that could not be separated. Struggle for Islam was a process to build the nation and country. And vice versa, building the country of Indonesia was also an effort of Islam syiar. For Gandusari Muhammadiyah branch leader, connection between Islam and the nation was like two faces of a coin, in which one side completed and gave meaning to the other, and the unavailability of one side meant the unavailability of the other. It had to be understood that Islam was exist in Indonesia, and that it had to be able to strenghthen the humanity values to continue the real contribution of Islam for the human and the universe.

Fields became the participation area in development for Muhammadiyah was widely spread covering all nation and society's life aspects namely: health, education, economy, social, art and culture. For each organizer from centre to branch could take some fields in accordance with their capacity and capability. Each of them at least had one field of charity effort. That was actually hoped by Muhammadiyah founder, K.H. Ahmad Dahlan. Organizerss could do nothing. They had to be active in doing creative activities which possibly contributed to the surrounding society.

Education at MTS Muhammadiyah was aimed to build a good character who obeyed Allah SWT, was able to communicate and interact with one another, had respon- 
sibility in forming the earth's prosperity. Such Education needed synergy between school and parents, society, and the world of business or business society. Relationship and interaction between school and the surrounding environment was an effort to implement school's willingness to introduce the students to any groups in the society. Introduction to the surrounding society was an effort for students to understand that in daily life, human needed others in any fields whatsoever. Thus, in developing the relationship, it would be the best if they could give more contribution and benefit for the environment.

The building of good character for each student was done by learning process at school. Character building according to the principal was not only in the form of knowledge gained form the aqidah and akhlak lesson, but also could be practiced in the real daily life. This habituation was emphasized in the form of rules which managed the daily mingle system. It was stated in listed rules and ethic codes which managed the students courtesies to mingle with each other, that was clause number 5 .

Citizenship education taught at school, for Muhammadiyah was a part that could form generation who were able to serve the society and the nation. In Muhammadiyah, to develop the affection for the country, there was a hizbul wathan extracurricular activity (HW). According to document learned by the researcher, there was a rule in clause number 1 saying that on Fridays and Saturdays, students had to wear Hizbul Wathan uniform, black shoes, black socks, black belt, and a necktie. HW activity was conducted on Saturdays after students did activities related to hobbies and interests. Each student in MTS Muhammadiyah Gandusari was compulsory to join the HW activity. It emphasized on forming a personal who was charactered, discipline, had a serving soul, faithful to the religion and nation, and had a responsibility for people and the society. Thus, the activities involved phisical and mental strength forming. Both were one unity, in which a health mental was in a health body, and a health body would become a health mental instrument as well.

One value could be learnt from $\mathrm{K}$. H Ahmad Dahlan's thought, ideas, goals and actions was his loyalti for the religion and the nation. This then could be patterned became religious and nation values for all Muhammadiyah followers. Muhammadiyah followers should have vision, attitude, and behavior faithfully commited to the importance of religion dakwah. This loyalty in this contect was understood as a worship value to which all Moslem were up to. Moreover, faithful to the nation in Islam taught was also considered as a worship. Worship for Moslem was an instrument to gain happiness in the world and in afterlife.

\section{Muhammadiyah 1 Vocational School - Trenggalek}

K.H. Ahmad Dahlan had inherited values, norms, and spirit which practiced Islamic teaching in daily life of its followers. Holding tightly those values would make them having hirroh in bringing Muhammadiyah alive as their manifestation from their loyalty to God and people surrounding. In Islamic teaching, this was a good kind of people, chosen people as taught by The Prophet of Muhammad SAW. That was people who gave benefit to the people surrounding. Spirit to be the best people gave birth to keep working attitude, in the aspect of knowledge, behavior, good deeds. Here was the importance of movement activity. Life was a movement because only dead creatures woud not move. Movement improved by Muhammadiyah was in the form of charity effort activity. Each of Muhammadiyah organizer office should have a charity effort in accordance with its internal and external potensial.

Movement may mean organisatory and individually. Organisatory meant that each Muhammadiyah official period should give birth a proudly achievement, which could be felt by its member in all fields of life. Each field and organizer level in Muhammadiyah should have routine or incidental programs and activities, phisical or non-phisical, and charity effort as well. On the other hand, individually, member of Muhammadiyah should have ideas, goals, and be able to form them in their dalily life in accordance with their own capacity, to make them benefitted to the people surrounding, started from the family, neighbours, and society for general. In running the charity effort, it should not only benefitted for the members, but also for all 
society with different educational background, social, economy, religion and or religious organizations.

Benefit of Muhammadiyah movement as inherited by K.H. Ahmad Dahlan was for all human being. This concept was reflected from Islamic teaching which was rahmatan lilalamin. K H. Ahamd Dahlan taught that if you did charity never looked at the receiver's background. Even The Prophet said prayers to the people who were mean to him. According to the respondent's utterance, K.H. Ahmad Dahlan was once taught Surah $\mathrm{Al}$ Maun to his students by explaining from the meaning literally (explicit meaning) to the meaning between the lines (implicit meaning) based on the surrounding reality. That theme was repeated many times or everyday that a student questioned him. Then K.H. Ahmad Dahlan asked his students to join him to Pringharjo market to buy foods and gave them away to the homeless and beggar around the market. Next, he explained to the students that it was one of the goals of his repeated lesson about Al-Maun, that was until it was implemented/practiced. It didn't need to know the background of the homeless and beggar; what was needed to know was that each of us should do good deeds to others and good workings for all people surrounding.

The charity efforts established by Trenggalek Muhammadiyah Leader was various. They were education institutions namely: Muhammadiyah Vocational School, Innovative Elementary School, MBS Boarding School, finance institution, orphanage, and Suryamart Supermarket. This education institutions establishment according to the respondent utterance was an implementation of amar maruf nahy munkar taught by K.H. Ahmad Dahlan. He said, "One background of $\mathrm{Mu}$ hammadiyah Vocational School establishment is that because Muhammadiyah teacher training school (SPG) which is successful before could no longer be defended." At that time it was because of the government policy to stop the teacher training program, including religion teacher training. (PGA). Muhammadiyah figures then did the late night worship to gain Allah SWT's guidance about shool which could give benefit for the surrounding society. Not long, they determined their heart and mind to build Muhammadiyah vocational school (SMEA) at the building of Muham- madiyah teacher training school (SPG) even the condition was very pitiful. This institution establishment according to the organizers' consideration was the implementation of amar maruf nahy munkar. (W.SW05.REP01.24032016)

Education institution was a right option to help the governement in increasing the level and quality of the nation's human resource. This was an effort to straighten goodnes for the nation and its people. School was a container which possibly produced generation who was able to dedicate their thought and energy for the goodness of the society. It became the supplier of human resource which in the future would dedicate the knowledge for the importance of nation's development. Constructing, for Muhammadiyah was for the goodness of people in society. This effort may reduce badness, idiocy, and treachery of people and nation. Treachery in this concept was not only related to the character but wider than that, also all things made the the nation and its people more left behind than other neighbouring countries.

In general, amar maruf needed to translate in accordance with the nation's dynamic context of the local society. Calling for goodness did not only mean in verbal aspect for character repair but also in action movement for giving real contribution for the nation and its people. Of course it was in the form of charity effort in all human's field of life such as education, economy, social, high level politics, culture and many others. In education field, it could establish institutions from the level of PG/Kindergarten up to universities, both general institution or religious based institutuion. In economy field, it could establish syariah economy institution such as Baitul Tamwil Muhammadiyah (BTM), credit-matter syariah bank (BPRS), insurance, tithe institution, and many others. In social field, it could establish orphanage, shelter for homeless, beggar and children who lived on streets. In the field of politics, member of Muhammadiyah could join a political party, or organizers could do lobbies which were possible to implement programs and activities that gave big contribution for society. In the field of culture, organizers could be pioneer in implementing activities which supported in growing and developing nation and its people's culture, which may produce a charac- 
tered society and ensoul the glorious nation's values inherited by the nation's warriors and founding fathers. Nahy munkar meant preventing bad effects happened to the nation and its people. Bad effects in this context covered all aspects in Indonesian people's life or the local society.

According to the organizer's consideration, these things could be saved by cutting the link of treachery by establishing education institution. It was with an assumption that if the member capability was getting better, they could give a real contribution directly or indirectly towards the family, nation and its people. Another consideration, by establishing education institution, it could develop the religion syiar. If there were more member and society increased their knowledge quality especially in memorizing the verses and short surahs from The Quran, then it was hoped they could improve their contribution toward the continuity of Islam religion and Muhammadiyah religious organization. As uttered by respondent to the researcher, alumnus of Muhammadiyah Vocational School had to have certain qualification that didn't owned by other state vocational schools. That was ability to memorize the verses and short surahs from The Quran, skill to take care corpse, do the worship for corpse, do the tayamum, wudhu and takjiyah in right ways in accordance with the Islamic teaching. (W.SW06.REP01.24032016)

For Muhammadiyah organizers, establishing education institution was the implementation of religious worship, and an effort to form the affection for the nation. Struggle in early stage of Muhammadiyah establishment could be done in any ways such as holding the weapons and involving in the battle directly against the imperialists. Another way was by fighting the idiocy in the form of establishing the education institution. In the independence era, affection for the nation could be formed in many ways in accordance with the problem faced by Indonesia country. The problems faced by Indonesia country was very complex so that it needed attention and contribution from all citizens in accordance with their own ability and capacity. According to the principal, who was one of Muhammadiyah Vocational School pioneers, that establishing education institution and other charity efforts was a possibility as part of nation's citizen. Anything could do would be done by Muhammadiyah and its followers to make them keep working for the nation. (W.SW06.REP02.24032016)

Meeting, The Quran recitation, and routine discussion were held by organizers for internal organizers themselves, members and general society in Trenggalek. Any ways were done by organizers to give the best for the nation and its people. One of them was by establishing or continuing Muhammadiyah teacher training school (SPG) into Muhammadiyah Vocational School (SMK). As vice principal said, it was very hard formerly in establishing this institution. One of the obstacles was students' tuition fee paying which was not paid for months that was difficult for the institution to fullfill its operational needs.(W.SW08.REP02.24032016)

To cope with this difficulty, administrators held a simple investigation about the daily life of the students' parents. The report showed that most of the parents raised other people's goats with the system of result sharing. From this finding, school gathered the students' parents and discussed how they could pay the tuition fees without losing their job (raising goats) and they even could get profit from the program. The daitail then was stated to the researcher. "Fortunately, we have 10 million fund. In the meeting we told them our finance condition and its operational needs to make them understand. Since most of them were farmers, we offer them paying the tuition fee by raising goats with the system of result sharing." This program was agreed by students' parents. The action taken then was giving them goats to raise. This program was successful. They were free from the unpaid tuition fee and also gained profit. It was as the saying, killing two birds with one stone. (W.SW06.REP02.24032016)

Establishment of Muhammadiyah vocational school was meant to dedicate the knowledge, skill and affection to the nation, as inherited by K.H. Ahmad Dahlan. So it was for that reason, in a free condition (independent), those efforts should be done more, in a discipline way, and giving all energy, thought, and time at most. These were motivation implemented in establishing the education institution. Education institution was considered as an important instrument in creating human resource that could play important role in the 
nation and its people's dynamic building process. Education was strategic instrument to produce human resource who was able to do jobs, to work and improve the nation and its people. It was noted in the result of tracer student developed by alumnus, that education institution took an important role in the society. There were many works of Muhammadiyah vocational school students exhibited locally, regionally and nationally. There was a fashion design from a student exhibited in national exhibition.

Another data related to the students work was the fashion designed with certain themes held once a year. This activity was meant to show all institutions administrators and organizers' caring. Every year the result of the fashion design was exhibited and many beauty institutions ordered them. As said by the respondent to the researcher, "Every year we hold student's achievement parade to show people outside in order to gain their interest and positive response towards the institution." This was also aimed to appreciate students who had designed the fashion well and highly valued. Many beauty institutions bought the result of the students' work. The price was various around $\mathrm{Rp} .800 .000$ up to $\mathrm{Rp}$ 1.500 .000 based on the material used. (W.SW08.REP02.24032016)

Education institution was an important instrument in giving birth of the next generation in the future. The more education institutions established by Muhammadiyah organizers, the more chance it got to present heirs to develop Muhammadiyah in the future. Various activities were hoped to be learning source for students in Muhammadiyah vocational school. They were not insisted, but free to be chosen based on students' interest and talent. Those activities were covered in extracurricular activities and aimed to develop students' interst and talent. In addition, the activities were used as a means to introduce Muhammadiyah's program and activities to the students. Some of the activities were Muhammadiyah Students Bond (IPM) and Hizbul Wathan (HW).

Based on a document learned by researcher, IPM was followed by 10 to 12 graders but not many. IPM organization was the substitution for the students union (OSIS). Since there was no OSIS, its existence was sustituted by IPM. This was aimed not too disturb students' learning time because they follow too many supporting activities. IPM programs and activities were focused on increasing knowledge capacity about Muhammadiyah, organization, and socio-religion. (W.SW08.REP03.24032016)

The period of IPM organization was for 1 year. It meant every 1 year they held reorganization and the former organizers may be chosen again maximum for two periods continually. Organization for students was an instrument to make them grown up, able to manage the institution and themselves, and develop program for the wider society's importance. Thus, it was understood that becoming IPM organizers could be a means of being Muhammadiyah generation in the future.

Another extracurricular activity which was important to be the students' basis of ability and skill was muhadhoroh activity (leadership and dakwah training). Muhadhoroh was practiced theoretically and practically. Theory material covered basic knowledge of leadership and dakwah (approach, strategy, methods and technique of dakwah). According to vice principal for students and public relation matter, muhadhoroh pratice taught students how to be a leader and dai about Muhammadiyah.

The principal confessed that many alumnus of Muhammadiyah vocational school had important roles in the society, which related to Muhammadiyah matter or organizations in their villages. They had various roles in accordance with their own intention, talent, interest, and field of work. This was also confessed by the vice principal that many society members spared their time to visit, see, and discussed about the roles of alumnus with the teachers they knew. The latent role of students or alumnus of Muhammadiyah vocational school in the society could not be separated from the planning (curriculum), persistence, discipline, and determination to build alumnus who had not only knowledge, ability and skill based on their majority, but also ability that the society wished for.

\section{Reflection of KH. Ahmad Dahlan's Educational Ideas}

It was quite difficult to trace K.H. Ahmad Dahlan's ideas especially the ones about education. He was not someone who liked writing; but he was a person who em- 
phasized more to behavior and action. This did not mean that his educational actions were not based on theories, or values, both from religious and society values. His education concept could be traced from his works, namely: Seven Religious Philosophy and Seventeen Groups of The Quran Verses. Actually, it was not written directly by K.H. Ahmad Dahlan, but by K.R.H. Hadjid, and Kyai Suja (Muarif, 2012, p. 80).

Education, for K.H. Ahmad Dahlan was part of adavancement thinking which was set of from comprehension towards Islam with modern perspective. The nature of religion, according to him was based on $Q S$. Al Ruum: 30 which could be reflected as follows: "Religion (is) the spiritual's intention (that turns around) from passions, rising above to the space of perfection, being sacred, being clean from entity imprisonment" (Hadjid, 2008, p. 68). Therefore, overlook (thy face straightly to Allah SWT's religion), hi Muhammad; which means intend yourself to Allah SWT's religion, by giving yourself wholeheartedly and people following you in undergoing His religion (Allah SWT's natural tendency), His creation (who has created human in accordance with the natural tendency that is His religion. It means that people are not allowed to substitute it, such as allying Him. (That is a straight religion). Tauhid religion is a straight religion (but most human), they are kafir people of Makkah (not knowing Allah SWT's oneness). Naturally, every human tends to his nature tendencion (accepting tauhid religion) and doesn't deny it. However, since their (munafiq people) mind and heart is covered with worldliness, they deny that natural tendency.

Naturally, religion was shining full of light. However, in the long run, religion overcasted because Moslem people turned into wordliness, loved wealth and position. For them, symbols of worldliness were more important than substances to reach happiness afterlife. Human forgot that the world was like a garden, a place for relaxing, that when the time came, they had to come back home, to afterlife. It was for that reason, human should have a clear thought, strong mind, and comprehensive knowledge. It was important to optimize the mind in nowadays life to gain comprehensive religious knowledge as stated below: "People have to and are compulsory to find additional knowledge; don't ever feel enough with their own knowledge, or even refuse others' knowledge. People need and are compulsory to run their main knowledge, never let only the knowledge remain..." (Dahlan, 1923).

Every human had a clear thought, healthy mind, clean heart, and modesty. Mind had an important role in human's life and it was mandated with the deity's revelation to play the important role to legitimate the revelation's truth and carry on all field of knowledge(Kamal, 2011, pp. 1-12). Healthy mind was the one able to differentiate between the nature of life's goal and worldliness life's goal. It also could differentiate between good and bad, wrong and right, things could and couldn't do (Miller \& Cohen, 2001, pp. 167-202). Clean heart was one covered with willingness of intention to goodness. The nature of mind could know, explain, synthesize and make decisions about urgent matters and had good impact towards life and life of society. Thus, it could be understood that mind in a personal and society's life for general had important position and role. It was for that reason, school should be purposed to form students' mind to be optimally developed.

School pioneered by K.H. Ahmad Dahlan was a model of school oriented to the forming of transendental and transformative knowledge for students. Charity, effort, and activity conducted by individual in this view was an implementation of belief towards allah SWT. The nature of tauhid had to be implemented, emitting spirit, emitting clarity in thinking and strong motivation. Each individual should have a maximum life orientation, that its presence had benefit for the family, society and nation. That's why, mind using, networking, and skill to give birth of the charity effort benefitted for wider society became a possibility. Thus, school pioneered by K.H. Ahmad Dahlan not only making the thinking mind could afford, but also having skill and sensitivity toward social problems.

Every student consisted of two important elements, they were physic and psychic. Both needed nutrient to grow and develop in accordance with its fate. Assignment for parents at home, teachers at school, and the society was providing the means and infrastructure, software and hardware needed by the students. 
Psychic, mental, and knowledge developed by school should be in the form of transendental knowledge. Attitude and consciousness of Allah SWT's presence (omni present) became the innerforce to move the students to keep learning (knowledge thirst). Knowledge owned by students should move their attitude and behavior to the goodness. Transendental knowledge supported individual of the students to be goodness agent, fighter, and modernist with high creativity to make the social environment better (Murniati, 2008, p. 2).

At that time, K.H. Ahmad Dahlan's idea was a revolutioner in the middle of Indonesian people's stagnation and idiocy condition. He inflamed the importance of education for people and society to gain general, religion and social knowledge. For K.H. Ahmad Dahlan, such comprehensive knowledge would make him to be leader who was on the side of nation and its people. Moreover, to be a leader who had advanced vision and able to pull and take the carriage into independence. Education institution could be understood as important instrument to gain the nation's independence.

Education was a process and means to reach perfection level, since human was created with potential to be perfect (physic and psychic). Human had a "to be" trait, an endless process. In Islamic concept, learning had to be started from mother's cradle to the death. Education was a growing up process; morally, notionly, and socially. Growing up was signed by ability and willingness to responsible towards one's own decision and independently on the thinking level, attitude and behavior.

Morally grown up was reached if one had been able to know ethics and good and bad from his own thinking, attitude and behavior and responsible for the consequences of his mind. Notionly grown up was signed if one made decision logically form each $d u$ niawi-ukhrowi problem he faced. Meanwhile, socially grown up was signed with willingness to carry the social responsibility, take social roles with other social components to create a more dignified society. This was actually the education role played by K.H. Ahmad Dahlan as instrument to form independence.

Education was directed as the instrument to straighten the Islamic taught and dakwah. This was relevant to the goal of Muhammadiyah education, that was straighten and carrying Islam to build a real Islamic society (Hamdan, 2009, p. 78). Since its establishment, Muhammadiyah was known as a modern organization (tajdid). Up to this time, it is also known as an organization which pioneers advanced paradigm. Advancement needed creativity ability, and high creativity based on ethics values would give birth to innerforce which could support the institution to be always oriented to advancement. For Muhammadiyah, advancement was oriented to the field of teaching and thinking. Advancement in teaching was emphasized on the purification of Islamic teaching by guidance of The Quran and Sunnah and using a healthy mind. Meanwhile, the advancement in thinking was improvement of thinking insight in the implementation of teaching related to muamalah duniawiyah which was permitted by syara or modernization in the world organizing in accordance with the Islamic teaching.

These two field for Muhammadiyah was one whole unity could not be separated or chosen one of them. The implementation of the two teaching field above would become basic values for the formation of a better nation and its people. Thus, it was generally understood that the setback of Islamic civilization in the forest of life was caused by too many people left Islamic teaching, for example the destruction of Andalusia.

A stronger hold toward the purity of The Quran and Sunnah teaching could give birth to a better society, nation and its people. It was modeled by The Prophet of Muhammad SAW. The Quran and Sunnah gave guidance, direction, and example about implementation of the nation and its people's life in any kind of aspects namely: polictics, economy, culture, education, art, science and technology. It was important for Moslems to always dig all the hidden pearls to become guided values so that the knowledge produced always had a strong support from the Islamic teaching. Recently, there were many modern inventions had a meeting point with Islamic teaching as contained in the Quran and Sunnah.

K.H. Ahmad Dahlan's view about the importance of religion was placed as the cornerstone of educational values which was 
inline with the advanced educational experts' vision. That educational knowledge was normative knowledge, and that education was not only describing, but also telling the need and necessity to reach an ideal goal or gain something that was better to be seen and tested from the life value (Muhajir, 2000, p. 2). Educational knowledge that was based on religious knowledge would give meaning towards the genuine of life orientation and goal. Education was not only an instrument to reach a better life, but more than that education also meant to optimize self's potential to give a greater benefit for people, society and nation. This was the nature of life hoped by the Islamic teaching. It was similarly aimed by K.H. ahmad Dahlan when establishing the first Muhammadiyah education institution by reviewing and implementing the meaning of Surah Al Maun.

Educational vision built by K.H. Ahmad Dahlan was suitable to his advice he kept telling to Muhammadiyah followers. "Be advanced kyai, and for Muhammadiyah." (Sucipto, 2010). Education developed by Muhammadiyah was to create kyai which was intellect and intellect which was kyai. Muhammadiyah education should produce alumnus which were qualified, able to think, analyze, and apply the Islamic values and teaching in their daily life. General objective of Muhammadiyah education according to K.H. Ahmad Dahlan covered: a) consideration and devotion to religion, b) having broad vision and devotion to general knowledge, c) willing to struggle for the society advancement (Sucipto, 2010).

Instrument to reach the goal covered: means of learning, teaching and educational staff, and curriculum to be taught to students. To reach the education objectives, material for education according to K.H. Ahmad Dahlan was The Quran and Hadits teaching, reading, writing, counting, geography, drawing and mantiq knowledge. The Quran and Hadits material covered: worship, level equation, function of human deeds in determining their fate, logical approval towards the truth of The Quran and Hadits, cooperationn between religion-culture for civilization advancement, causality adjustment law, passion and willingness, democracy and liberalisation, freedom of thinking, life dynamics and human role within it and akhlak (Sucipto, 2010).
Muhammadiyah curriculum was integration between general education orientation and religion education. This was purposed to make sure of the achievement of education objectives which was to create ulama which was intellect and intellect which was ulama. It was commonly known that curriculum improved by Muhammadiyah in the early stage were: building the education places where religious and general knowlede were taught together, and giving additional religious lesson to secular general schools (Sucipto, 2010, p. 119). General lesson was purposed to provide the students to master the science and become intellectual. Meanwhile, religion lesson was purposed to provide the students with religion knowledge to have ulama qualification. This was based on The Quran for example stated in the proverb of afala tatafakkarun, afala yukminun, ulul albab.

Islamic education should be set of from the effort of mind improvement through educational process which would be end at the growth of creativity and giving implication for Muhammadiyah people to have advancement spirit (tajdid) in Islamic education (Sucipto, 2010). Creativity was a function of human brain ability to cope with the dynamic changing in the society. It was purposed to dinamise and organize the dynamics for the beter advancement of human civilisation as the Motto of Muhammadiyah that was advanced Islam.

Orientation for curriculum development of Muhammadiyah education as mentioned above was reflected on the personal of K.H. Ahmad Dahlan. It was: as a seeker of natural truth who caught what was implicitly contained in Al-Manaar commentation. Though he didn't have west education background, but he opened widely the gate of rationality through the Islamic teaching itself. He called for ijtihad and refused taqlid. It could be said that he was a "model" from a generation ressurection which became "the centre point" from a movement, rising to answer the challenges faced by Islam groups which was in the form of lag in education system and stagnation concept in Islam.

At that time, differ from the other national figures who paid more attention to politics and economics matters, K.H. ahmad Dahlan dedicated himself wholy in the field of education. Orientation point to the education world on its turn drove him to the heart of the 
real problem of the people. In the run with the rolling of ethics or association politics (since 1990), the Holland school expansion was projected as a new form of imperialism which was hoped to slide Islamic education institutions such as pesantren. Education in Indonesia then splitted into two, they were: the secular Holland schools which knew nothing about religion teaching; and education in pesantren which only taught material related to religion.

Teaching method developed by K.H. ahmad Dahlan had a contextual design through consciousnes process. As a classical example was when he explained Surah Al Maun to his students repeatedly until they realized that it advised them to care and help the poor, and had to implement the content. After the students implemented that order, they came to the next surah. Spirit had to develop by Muhammadiyah teachers was how to improve value and pattern the system of learning Al Maun as practiced by K.H. Ahmad Dahlan. However, what was inherited by Muhammadiyah people was the education techniques, not the goals, soul, spirit and value to free the society from poverty, idiocy, and stagnation. Thus, it wouln't be strange if there were people who couldn't receive education innovation at Muhammadiyah institution. Education innovation was considered as bidah. Actually, what was to be learned from K.H. Ahmad dahlan was his spirit to make alteration or advancement ethos, not the form or the ijtihad result.

Based on data collected, when $\mathrm{Mu}$ hammadiyah figures in Gandusari Subdistrict established Madrasah Tsanawiyah (MTs) education institution, they were inspired by the fighting spirit of K.H. Ahmad Dahlan especially the self benefit values towards the surrounding society. This attitude was based on transendental consciousness, faith towards Allah SWT who was as God underwent a metamorphosis and became driving force (energy) to make oneself as a personal who inherited god's values forming in daily behavior which was full of affection, love to help, polite in talking, delicate in behavior, and always develop himself to be a benefitted person for various people surrounding. This attitude was formed by establishing Madrasah Tsanawiyah (MTs) which was needed at that time by the surrounding society. At that time, there were already two state junior high school exist. On the other hand, however, society still needed a religion based school. They realized that religion education during the puberty age was important to be planted to their children. Through psychology science perspective, periodically, children in puberty era would have outside orientation (extrovert) and find model outside themselves. Thus, giving religious education foundation to them was a right choice (Nisfiannoor \& Kartika, 2004, pp. 160-177).

The spirit of tajdid, advancement was spirit of creativity power and innovative (Ahmad, 2015, pp. 144-154). K.H. Ahmad Dahlan taught these values which was summarized in the values and teaching of amar maruf, in which calling for goodness was not only limited to rethorical meaning, but also with cultural meaning, down to earth, and real action. Calling for goodness (amar ma'ruf) was meant by its urge to create instrument or means to form one goodness in knowledge, attitude, and behavior in the society. Spirit in establishing MTs in Gandusari and Muhammadiyah 1 Vocational School in Trenggalek was the form of the teaching values. School was a formal institution for people and nation training. Thus, establishing schools could be meant as a long term effort to form the goodness of the society. The more member of society who had knowledge and the higher level of their education, the better behavior was formed in the society. The more good people, the higher quality of self improvement effort to be benefitted citizen for the nation and its people.

To prevent treachery in contextual meaning was how to reduce badness, deficiency, and stupidity in religious and general knowledge or bad traits in the society. Knowledge was understood as the main requirement to form life of society, nation, religion. Of course, knowledge which was suit to the values of K.H Ahmad Dahlan's teaching was contextual and dynamic. It was hoped that by establishing education isntitution in a long term could reduce TBC attitude, culture, social, and economy backwardness. Establishing education institution was understood as an important instrument to reduce deficiency in the society for a long term. It was for that reason, at that time, Muhammadiyah figures in Gandusari and Trenggalek had a high spirit 
and were even willing to sacrifice energy, fund, and time they owned to be given away as jariyah charity in establishing MTs and Vocational School.

\section{CONCLUSION}

Reflection of K.H. Ahmad Dahlan's educational ideas was to develop schools. First, at MTs Muhammadiyah Gandusari, it covered: (a) Muhammadiyah values, such as, TBC eradication, the improvement of fundamentalist religious culture in the society. (b) willingness to sacrifice attitude growth by school founders' core team, organizers, and administrators to give away their time, wealth and energy.(c) dakwah and dedication for the nation and country. Second, at Muhammadiyah 1 Vocational School, it covered: (a) Charity effort movement for all (rahmatan lilalamin), (b) amar maruf nahy munkar was formed in all aspects construction, (c) working was the spirit as movement organization

\section{REFERENCES}

Ahmad, F. (2015). Pemikiran K.H. Ahmad Dahlan tentang pendidikan dan implementasinya di SMP Muhammadiyah 6 Yogyakarta tahun 2014/2015. Profetika: Jurnal Studi Islam, 16(2), 144-154. Retrieved from http://journals.ums.ac.id/index.php/profe tika/article/view/1854

Dahlan, A. (1923). Tali pengikat hidup manusia. Yogyakarta: Hoofdbestuur Muhammadiyah Bagian Taman Pustaka.

Hadjid, K. R. H. (2008). Tujuh falsafah ajaran dan 17 Kelompok ayat-ayat alquran. Yogyakarta: LPI PPM.

Hamdan. (2009). Paradigma baru pendidikan Muhammadiyah. Yogyakarta: Ar-Ruz media.

Hefner, R. W., Mulyadi, S., \& Mulkhan, A. M. (2008). Api pembaharuan kiai Ahmad Dahlan. Yogyakarta: Multi Pressindo.

Imron, A. (2009). Manajemen mutu sekolah berbasis religi, studi multi kasus pada SD Mintu, SD Iwaha, SD Kasayuga, dan SD Kripe. Disertasi, tidak diterbitkan.
Universitas Negeri Malang.

Kamal, H. M. (2011). The human intellect, divine revelation and knowledge based on Al-qaradhowi's work. Revelation and Science, 1(03 (Special Issue)). Retrieved from

http://journals.iium.edu.my/revival/index .php/revival/article/view/35

Malik, A., Sudrajat, A., \& Hanum, F. (2016). Kultur pendidikan pesantren dan radikalisme. Jurnal Pembangunan Pendidikan: Fondasi Dan Aplikasi, 4(2), 103. https://doi.org/10.21831/jppfa.v4i2.1127 9

Miller, E. K., \& Cohen, J. D. (2001). An integrative theory of prefrontal cortex function. Annual Review of Neuroscience, 24(1), 167-202. https://doi.org/10.1146/annurev.neuro.24 .1 .167

Muarif. (2012). Modernisasi pendidikan islam, sejarah dan perkembangan kweekschool moehammadiyah. Yogyakarta: Suara Muhammadiyah.

Muhajir, N. (2000). Ilmu pendidikan dan perubahan sosial. Yogyakarta: Rake Sarasain.

Murniati, A. R. (2008). Manajemen stratejik: peran kepala sekolah dalam pemberdayaan. Bandung: Cipta Pustaka.

Nisfiannoor, M., \& Kartika, Y. (2004). Hubungan antara regulasi emosi dan penerimaan kelompok teman sebaya pada remaja. Jurnal Psikologi, 2(2), 160-177.

Samidjo. (2008). Ciri-ciri kepala sekolah yang efektif pada sekolah menengah kejuruan (studi kasus di SMK Merapi dan SMK Merbabu. Jurnal Pendidikan Dan Kebudayaan, 74(14), 1170-1196.

Sucipto, H. (2010). KH. Ahmad Dahlan sang pencerah, pendidik, dan pendiri Muammadiyah. Jakarta: Best Media Utama.

Zamroni, Z. (2001). Paradigma pendidikan masa depan. Yogyakarta: Bigraf Publishing. 